\title{
Duration of rise in free fatty acids determines salicylate's effect on hepatic insulin sensitivity
}

\author{
Sandra Pereira', Wen Qin Yu', María E Frigolet ${ }^{2,3}$, Jacqueline L Beaudry ${ }^{4}$, \\ Yaniv Shpilberg ${ }^{4}$, Edward Park', Cristina Dirlea', B L Grégoire Nyomba ${ }^{5}$, \\ Michael C Riddell ${ }^{4}$, I George Fantus ${ }^{1,2,3}$ and Adria Giacca' \\ ${ }^{1}$ Department of Physiology, University of Toronto, Medical Sciences Building, 1 King's College Circle, Toronto, \\ Ontario, Canada M5S 1A8 \\ ${ }^{2}$ Department of Medicine, Mount Sinai Hospital, Toronto, Ontario, Canada \\ ${ }^{3}$ Toronto General Research Institute and Banting and Best Diabetes Centre, University Health Network, Toronto, \\ Ontario, Canada \\ ${ }^{4}$ Muscle Health Research Center and Physical Activity and Chronic Disease Unit, Faculty of Health, School of \\ Kinesiology and Health Science, York University, Toronto, Ontario, Canada \\ ${ }^{5}$ Department of Internal Medicine, University of Manitoba, Winnipeg, Manitoba, Canada
}

Correspondence should be addressed to A Giacca

Email adria.giacca@utoronto.ca

\begin{abstract}
We have shown in rats that sodium salicylate (SS), which inhibits IkBa kinase B (IKKB), prevents hepatic and peripheral insulin resistance caused by short-term ( $7 \mathrm{~h}$ ) i.v. administration of Intralipid and heparin $(\mathrm{IH})$. We wished to further determine whether this beneficial effect of SS persisted after prolonged (48 h) IH infusion, which better mimics the chronic free fatty acid (FFA) elevation of obesity. Hence, we performed hyperinsulinemic euglycemic clamps with tritiated glucose methodology to determine hepatic and peripheral insulin sensitivity in rats infused with saline, IH, IH and SS, or SS alone. SS prevented peripheral insulin resistance $(P<0.05)$ caused by prolonged plasma FFA elevation; however, it did not prevent hepatic insulin resistance. In skeletal muscle, protein levels of phospho$\mathrm{IkBa}$ were augmented by prolonged IH administration and this was prevented by SS, suggesting that IH activates while SS prevents the activation of IKKB. Markers of IKKB activation, namely protein levels of phospho-IkBa and IkBa, indicated that IKKB is not activated in the liver after prolonged FFA elevation. Phosphorylation of serine 307 at insulin receptor substrate (IRS)-1, which is a marker of proximal insulin resistance, was not altered by $\mathrm{IH}$ administration in the liver, suggesting that this is not a site of hepatic insulin resistance in the prolonged lipid infusion model. Our results suggest that the role of IKKB in fat-induced insulin resistance is time and tissue dependent and that hepatic insulin resistance induced by prolonged lipid elevation is not due to an IRS-1 serine 307 kinase.
\end{abstract}
Key Words
- free fatty acids
- insulin resistance
- liver
- glucose metabolism

Journal of Endocrinology (2013) 217, 31-43

\section{Introduction}

Obesity leads to type 2 diabetes mellitus (T2DM) because of insulin resistance, and insulin resistance of obesity is due to elevated circulating levels of free fatty acids (FFAs) and cytokines (Boden 1997, Lewis et al. 2002, Galic et al. 2010). Inhibitor of $\mathrm{kBa}$ kinase $\mathrm{B}$ (IKKB), a serine/threonine kinase that is associated with insulin resistance, can be

Published by Bioscientifica Ltd.

This is an Open Access article distributed under the terms of the Society for

Endocrinology's Re-use Licence which permits unrestricted non-commercial use 23 01:18:04AM distribution, and reproduction in any medium, provided the original work is properly. cited. 
activated by FFAs and cytokines (Boden et al. 2005, Park et al. 2007, Grund et al. 2008). The mechanisms through which IKKB induces insulin resistance are twofold: i) direct phosphorylation of insulin receptor substrate (IRS)-1 at serine 307 (Gao et al. 2002), which impairs tyrosine phosphorylation of IRS-1 and therefore dampens the insulin signal (Aguirre et al. 2000), and ii) activation of the transcription factor nuclear factor kB (NF-kB), which upregulates the expression of various cytokines (Barnes \& Karin 1997). NF-kB is inhibited when bound to IkBa in the cytoplasm, but upon phosphorylation of IkBa by activated IKKB, IkBa degradation is induced, culminating in the liberation and nuclear translocation of NF-kB (Ghosh \& Baltimore 1990, Brown et al. 1995, Traenckner et al. 1995, Zandi et al. 1998, Karin 1999, Hacker \& Karin 2006). IKKB is inhibited by salicylates, such as aspirin and sodium salicylate (SS; Yin et al. 1998).

Results obtained using rodent models show that IKKB mediates insulin resistance in multiple tissues. Hepatic overexpression of IKKB results in hepatic and peripheral insulin resistance (Cai et al. 2005). Hepatocyte-specific IKKB knockout (KO) mice show improved hepatic insulin sensitivity when challenged with high-fat feeding (Arkan et al. 2005). Salicylates ameliorate glucose tolerance as well as hepatic and skeletal muscle insulin signaling in Zucker fa/fa rats (Yuan et al. 2001). The role of IKKB in mediating insulin resistance is more controversial in humans than in rodents, as studies in humans have found salicylates to improve, decrease, or have no effect on insulin sensitivity (Newman \& Brodows 1983, Hundal et al. 2002, Koska et al. 2009, Xiao et al. 2009). In patients with T2DM, aspirin has been found to alleviate peripheral insulin resistance, although no improvement was found in hepatic insulin sensitivity (Hundal et al. 2002).

I.v. lipid infusions have been used to determine the role of IKKB in insulin resistance induced by FFAs per se, as opposed to insulin resistance induced by other factors associated with obesity. Short-term lipid infusions represent the obesity-associated amplified acute increases in tissue FFA availability in the fasting-feeding cycle, while prolonged lipid infusions more closely approximate the chronically augmented plasma FFA concentrations found in obesity. Heterozygous IKKB KO mice are protected from whole-body and peripheral insulin resistance caused by short-term (5 h) lipid infusion (Kim et al. 2001). SS also prevents peripheral (Kim et al. 2001, Park et al. 2007) and hepatic (Park et al. 2007) FFA-induced insulin resistance caused by short-term lipid infusion in rats. In humans, salicylates have been reported to improve (Mohlig et al. 2006) or have no effect (Meex et al. 2011) on insulin resistance caused by short-term lipid infusion. Using prolonged $(48 \mathrm{~h})$ lipid (Intralipid plus heparin, IH) infusion, our group has found that SS does not improve whole-body insulin resistance caused by prolonged plasma FFA elevation, although hepatic insulin sensitivity was not assessed (Xiao et al. 2009). The controversy surrounding the effectiveness of salicylates in improving insulin resistance in humans may be due to different dosages and types of salicylates used, and the often used oral route of administration, which limits the extent of bioavailability (Xiao et al. 2009). Studies on rodents facilitate the use of i.v. administration of salicylates and allow the collection of hepatic tissue for analysis of mediators and markers of insulin resistance. Therefore, in the current study, we sought to determine, in rodents, whether SS prevents hepatic and peripheral insulin resistance caused by prolonged ( $48 \mathrm{~h}$ ) lipid (IH) infusion, as it did after short-term lipid infusion (Park et al. 2007).

\section{Materials and methods}

\section{Animals}

Female Wistar rats weighing 250-300 g were obtained from Charles River (Saint-Constant, QC, Canada) and housed in the Department of Comparative Medicine of the University of Toronto. Rats had free access to standard chow (Teklad Global Diet \#2018; Harland Laboratories, Indianapolis, IN, USA) and water. All procedures were approved by the Animal Care Committee of the University of Toronto.

\section{Surgery}

Surgery was performed under isoflurane anesthesia, following 7-14 days of adaptation to the animal facility. Briefly, indwelling catheters were inserted into the right internal jugular vein for infusion and the left carotid artery for blood sampling, as described previously (Lam et al. 2002, Park et al. 2007). Post-surgery recovery was at least 3 days.

\section{Study design}

On the first experiment day, the cannulated rats were placed in a circular cage and connected to the infusion apparatus, as described previously (Mason et al. 1999). After a basal blood sample was obtained (time $=0 \mathrm{~h}$ ), rats were given one of four i.v. treatments for $48 \mathrm{~h}$ : saline ( $5.5 \mu \mathrm{l} / \mathrm{min})$, IH (20\% Intralipid plus $20 \mathrm{U} / \mathrm{ml}$ heparin at

Published by Bioscientifica Ltd. 
$5.5 \mu \mathrm{l} / \mathrm{min}$ ), IH plus SS (Sigma-Aldrich) $(7 \mathrm{mg} / \mathrm{kg}$ bolus plus $0.117 \mathrm{mg} / \mathrm{kg}$ per min), or SS alone. Heparinized saline $(4 \mathrm{U} / \mathrm{ml})$ was infused at $5 \mu \mathrm{l} / \mathrm{min}$ into the carotid artery from $0 \mathrm{~h}$ to the $44 \mathrm{~h}$ mark to maintain patency. Blood samples were obtained at $18 \mathrm{~h}$ as well as $24 \mathrm{~h}$ and rats were fasted overnight. On clamp day, a blood sample was obtained at $44 \mathrm{~h}$ and immediately afterward, an $8 \mu \mathrm{Ci}$ bolus of $\left[3-{ }^{3} \mathrm{H}\right]$ glucose (Perkin-Elmer, Boston, MA, USA) was given, followed by a constant $\left[3-{ }^{3} \mathrm{H}\right]$ glucose infusion of $0.15 \mu \mathrm{Ci} / \mathrm{min}$ that lasted until the end of treatment (time $=48 \mathrm{~h})$. Insulin $(5 \mathrm{mU} / \mathrm{kg}$ per min, Humulin R, Eli Lilly Canada) infusion was started at $46 \mathrm{~h}$ and plasma glucose was measured every 5 min using a glucose analyzer (Analox GM9D Analyser, Analox Instruments, Hammersmith, UK) and the infusion rate of a 50\% glucose solution was altered accordingly to maintain euglycemia (Park et al. 2007). The glucose solution contained $48 \mu \mathrm{Ci} / \mathrm{g}\left[3{ }^{3} \mathrm{H}\right]$ glucose to minimize decreases in plasma glucose specific activity, which are associated with underestimation of glucose production (Finegood et al. 1987). The $30 \mathrm{~min}$ before the start of insulin infusion is referred to as the basal period, while the last $30 \mathrm{~min}$ of the clamp are referred to as the clamp period. During the basal period and the clamp period, blood samples were obtained every 10 min to determine plasma glucose, FFA, insulin, and $\left[3-{ }^{3} \mathrm{H}\right]$ glucose specific activity. Once plasma was collected from centrifuged blood samples, red blood cells were mixed with heparinized saline $(2 \mathrm{U} / \mathrm{ml})$ in a $1: 1$ ratio and re-infused into animals. At the end of the clamp, rats were anesthetized, the liver was freeze-clamped with pre-cooled aluminum tongs, and the soleus muscle was collected. Tissues were stored at $-80^{\circ} \mathrm{C}$. The tissue determinations have a lower $n$ than the glucose kinetics determinations because we lost some tissue samples due to a freezer meltdown.

We have already shown that SS prevents IH-induced hepatic and peripheral insulin resistance in the 7-h model, which is analogous to the 48 -h i.v. infusion model described above with the exception of treatments being shorter in time (Park et al. 2007). To avoid comparison with historical controls, 7-h studies were repeated using the same dosage of SS as in the 48-h studies, which is also the dosage of SS we previously found to prevent insulin resistance induced by 7 -h IH infusion. The study design for these repeat 7-h studies was similar to that of the 48-h protocol, but all rats were infused with saline $(5.5 \mu \mathrm{l} / \mathrm{min})$ via the jugular vein from 0 to $41 \mathrm{~h}$, and then on clamp day, at $41 \mathrm{~h}$, rats were randomized into one of the four i.v. treatment groups that lasted $7 \mathrm{~h}$ : saline ( $5.5 \mu \mathrm{l} / \mathrm{min})$, IH ( $5.5 \mu \mathrm{l} / \mathrm{min})$, IH plus SS ( $\mathrm{mg} / \mathrm{kg}$ bolus plus
$0.117 \mathrm{mg} / \mathrm{kg}$ per $\mathrm{min})$, or SS alone. As for the 48 -h protocol, $\left[3-{ }^{3} \mathrm{H}\right]$ glucose infusion was started $4 \mathrm{~h}$ before the end of treatment and a hyperinsulinemic $(5 \mathrm{mU} / \mathrm{kg}$ per $\mathrm{min})$ euglycemic clamp with concomitant $\left[3-{ }^{3} \mathrm{H}\right]$ glucose methodology was performed during the last $2 \mathrm{~h}$ of treatment.

\section{Plasma assays}

To measure $\left[3-{ }^{3} \mathrm{H}\right]$ glucose in plasma and in glucose infusates, samples were deproteinized using $\mathrm{Ba}(\mathrm{OH})_{2}$ and $\mathrm{ZnSO}_{4}$, and after complete evaporation, radioactivity was counted (Park et al. 2007). Plasma insulin concentrations were determined by RIA (Millipore, Billerica, MA, USA) (Park et al. 2007). Plasma FFA concentrations were determined using a colorimetric assay (Wako Pure Chemical Industries, Ltd, Osaka, Japan) (Park et al. 2007). Plasma adiponectin concentrations during the basal period were determined using a kit (Cat \# EZRADP-62K, EMD Millipore) and 1:500 dilution of samples.

\section{Tissue preparation for western blot analysis}

Liver Liver tissue ( $50 \mathrm{mg}$ ) was homogenized by sonication using a lysis buffer consisting of $20 \mathrm{mM}$ Tris- $\mathrm{HCl}$ (pH 7.4), $1 \%$ Triton X-100, 10\% glycerol, $150 \mathrm{mM} \mathrm{NaCl}$, $2 \mathrm{mM}$ EDTA, $25 \mathrm{mM}$-glycerophosphate, $20 \mathrm{mM} \mathrm{NaF}$, $1 \mathrm{mM} \mathrm{Na} \mathrm{VO}_{4}, 2 \mathrm{mM}$ sodium pyrophosphate, $20 \mu \mathrm{M}$ leupeptin, $1 \mathrm{mM}$ benzamidine, $1 \mathrm{mM}$ 4-(2-aminoethyl)benzenesulfonyl fluoride hydrochloride, and $0.5 \mu \mathrm{M}$ okadaic acid. After centrifugation, the supernatant was stored at $-80^{\circ} \mathrm{C}$. For western blot analysis of protein kinase $\mathrm{C}(\mathrm{PKC})-\delta$, liver cytosolic and membrane fractions were obtained as described previously (Park et al. 2007), except that $0.5 \mu \mathrm{M}$ okadaic acid was used instead of $1 \mu \mathrm{M}$ microcystin.

Muscle For phospho-IkBa and total IkBa, soleus muscle samples of $50 \mathrm{mg}$ were homogenized using a glass homogenizer and a lysis buffer consisting of $128 \mathrm{mM} \mathrm{NaCl}$,

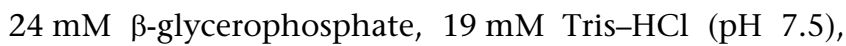
$2 \mathrm{mM}$ EDTA, $2 \mathrm{mM}$ sodium pyrophosphate, $2 \mathrm{mM}$ DL-dithiothreitol, $3 \mathrm{mM} \mathrm{Na}_{3} \mathrm{VO}_{4}, 10 \%$ glycerol, $1 \%$ Triton $\mathrm{X}-100,1.4 \mu \mathrm{g} / \mathrm{ml}$ aprotinin, $1 \mu \mathrm{g} / \mathrm{ml}$ okadaic acid, $1 \mathrm{mM}$ phenylmethylsulfonylfluoride (PMSF), and 19 mM HEPES. Following centrifugation, the supernatant was stored at $-80^{\circ} \mathrm{C}$. For soleus muscle phospho-IRS- 1 and total IRS-1, the lysis buffer consisted of $50 \mathrm{mM}$ Tris $\mathrm{pH} 7.5$, $1 \%$ Nonidet P-40, $150 \mathrm{mM} \mathrm{NaCl}, 1 \mathrm{mM} \mathrm{MgCl}_{2}, 1 \mathrm{mM}$ $\mathrm{CaCl}_{2}, 2 \mathrm{mM}$ EGTA, $10 \mathrm{mM}$ sodium pyrophosphate,

Published by Bioscientifica Ltd 
$100 \mathrm{mM} \mathrm{NaF}, 10 \mu \mathrm{g} / \mathrm{ml}$ aprotinin, $10 \mu \mathrm{g} / \mathrm{ml}$ leupeptin, $50 \mathrm{nM}$ okadaic acid, $1 \mathrm{mM}$ PMSF, and $1 \mathrm{mM} \mathrm{Na}_{3} \mathrm{VO}_{4}$. Following centrifugation, the supernatant was stored at $-80^{\circ} \mathrm{C}$.

\section{Western blot analysis}

Protein concentration was determined using the Bradford method (Bio-Rad Laboratories). Dried liver and muscle samples were mixed with Laemmli buffer boiled, loaded onto an electrophoretic apparatus, and subjected to SDS-PAGE. Subsequently, proteins were transferred to polyvinylidene fluoride membranes. Membranes were then blocked by incubating with $5 \%$ non-fat milk in Tris-buffered saline-Tween (TBST). For membranes that were probed for phospho-proteins, 5\% BSA in TBST was used for blocking. Next, membranes were incubated with primary antibodies. The following primary antibodies were used: rabbit polyclonal antibody against serine 32- and serine 36-phosphorylated IkBa (Santa Cruz Biotechnology, Santa Cruz, CA, USA), rabbit polyclonal anti-IkBa antibody (Santa Cruz), mouse monoclonal antia-tubulin antibody (Santa Cruz), goat polyclonal anti-actin antibody (Santa Cruz), rabbit polyclonal antibody against serine 307-phosphorylated IRS-1 (Millipore, Temecula, CA, USA), rabbit polyclonal anti-IRS-1 antibody (Millipore), rabbit polyclonal antibody against serine 473-phosphorylated Akt (Cell Signaling Technology, Danvers, MA, USA), rabbit polyclonal anti-Akt antibody (Cell Signaling Technology), and rabbit polyclonal anti-PKC- $\delta$ antibody (Santa Cruz). The following day, membranes were washed with TBST and incubated with secondary antibodies (all from Santa Cruz and conjugated with HRP). Afterward, membranes were washed with TBST. ECL substrate (ThermoScientific, Rockford, IL, USA) was used to develop the membranes. Membranes that were probed for phospho-IkBa, IkBa, phospho-IRS-1, and phospho-Akt were subsequently stripped and reprobed for IkBa, $\alpha$-tubulin (for muscle samples) or actin (for liver samples), IRS-1, or Akt respectively. Developed membranes were rinsed with TBST, stripped with stripping buffer (ThermoScientific), and washed with TBST. Blocking and subsequent steps were done as described above.

Quantification of the bands obtained on film was done using ImageJ (National Institutes of Health, Bethesda, MD, USA).

\section{Quantitative real-time PCR (qRT-PCR)}

Total RNA was extracted using the RNeasy Mini extraction kit (Qiagen) and subjected to RT before PCR amplification with the Two-Step Master Mix (Applied Biosystems). TaqMan fluorogenic probes and oligonucleotide primers were designed by Applied Biosystems. TaqMan PCR assays were carried out in triplicate in 96-well optical plates with an ABI PRISM 7900HT Sequence Detection System (Applied Biosystems). For every PCR sample, an amplification plot was generated from the collected data, and a threshold cycle (CT) value was calculated with the software suite. CT values were used to calculate the initial quantity of cDNA by substracting the $C$ T value of $\beta$-actin (Actb), which was used as a housekeeping gene. The real-time quantitative PCR data were analyzed using the $2^{-\triangle \triangle C T}$ method of Livak \& Schmittgen (2001). TaqMan assays for interleukin6 (Il6) (Rn01410330_m1), phosphoenolpyruvate carboxykinase (Pck1) (Rn01529014_m1), tumor necrosis factor- $\alpha$ (Tnf) (Rn01525859_g1), and Actb (Rn00667869_m1) were obtained from Applied Biosystems.

\section{Calculations of glucose kinetics}

Calculations of the rate of glucose disappearance $\left(R_{d}\right)$ and of endogenous glucose production (EGP) were done based on $\left[3-{ }^{3} \mathrm{H}\right]$ glucose data and using modified Steele's equations that take into account the tracer included in the glucose infusion during the clamp (Steele et al. 1956, Finegood etal. 1987). During the basal period, $\mathrm{R}_{\mathrm{d}}$ equals EGP. During the clamp period, $R_{d}$ equals the sum of the rate of exogenous glucose infusion and EGP. During euglycemia, $R_{d}$ represents glucose utilization by tissues because renal glucose clearance equals zero (Park et al. 2007). Averages of EGP and $\mathrm{R}_{\mathrm{d}}$ for the basal and clamp periods (steady state) as well as the average of the glucose infusion rate during the clamp period were calculated and presented herein.

\section{Statistical analysis}

Data are presented as means ts.E.M. To compare parameters between more than two treatment groups, one-way ANOVA was used and post hoc analysis was done using Tukey's test. When comparing parameters between two treatment groups, the independent samples $t$-test was used. Significance was set at 0.05 . Statistical analysis was carried out using IBM SPSS Statistics, Version 20 (IBM Corporation, Armonk, NY, USA).

\section{Results}

Prolonged lipid administration increased plasma FFA concentrations by $\sim 1.5$-fold during the basal period (last $30 \mathrm{~min}$ before the start of the hyperinsulinemic

Published by Bioscientifica Ltd 
euglycemic clamp) in both the IH-treated group and the group co-infused with IH and SS compared with controls $(P<0.05$, Table 1$)$. During the last $30 \mathrm{~min}$ of the hyperinsulinemic euglycemic clamp (clamp period), plasma FFA concentrations were also higher in the IH and co-infusion groups $(P<0.05$, Table 1$)$. SS did not appear to affect insulin-induced suppression of FFA, as previously found after $7 \mathrm{~h}$ of lipid infusion and consistent with a lack of effect of IH on markers of IKKB activation in fat (Park et al. 2007). Insulin concentrations were higher during the basal period in the IH group compared with the co-infusion and SS alone groups $(P<0.05$, Table 1$)$, likely secondary to insulin resistance. There were no differences in insulin concentrations between groups during the clamp (Table 1). Basal EGP corresponds to basal $\mathrm{R}_{\mathrm{d}}$ and it was higher in the IH group vs the other groups $(P<0.05$, Fig. 1A). Co-infusion with SS appeared to normalize basal EGP-R $\mathrm{R}_{\mathrm{d}}$ as well as basal hyperinsulinemia. During the hyperinsulinemic clamp, EGP was suppressed as expected, but it was higher in the $\mathrm{IH}$ and co-infusion groups (Fig. 1A). Percentage suppression of EGP from basal indicates that SS did not prevent hepatic insulin resistance caused by prolonged IH administration (Fig. 1B). However, the decrease in insulin-stimulated glucose utilization caused by prolonged IH administration was completely prevented by SS co-administration (Fig. 2A). As the glucose infusion rate, which is indicative of whole-body insulin sensitivity, is the difference between glucose utilization and EGP during the clamp period, we found that SS only partially prevents whole-body insulin resistance caused by prolonged IH treatment (Fig. 2B). In contrast with these results, we have previously shown that SS completely prevents whole-body, hepatic, and peripheral insulin resistance caused by short-term $(7 \mathrm{~h}) \mathrm{IH}$ infusion in rats (Park et al. 2007). To avoid historical controls, the studies were repeated and we found the same results (Figs 3 and 4).
We also examined liver and skeletal muscle tissues collected after the hyperinsulinemic euglycemic clamp in the prolonged infusion model for markers of IKKB activation and insulin sensitivity. IKKB activation causes the degradation of IkBa protein, and, hence, a decrease in IkBa protein content is often used as a marker of IKKB activation. We found that prolonged $\mathrm{IH}$ administration does not affect IkBa protein levels in the liver (Fig. 5A), suggesting that IKKB is not activated after prolonged plasma FFA elevation. We also determined the extent of serine 32 and serine 36 phosphorylation of IkBa as a more direct indicator of IKKB activation, compared to IkBa protein levels (DiDonato et al. 1995) because IKKB directly phosphorylates IkBa at serine 32 and 36 , and it is this phosphorylation that results in the degradation of IkBa (Brown et al. 1995, Zandi et al. 1998, Hacker \& Karin 2006). In liver tissue, we found that the content of phosphorylated IkBa at serine 32 and 36 divided by the content of total IkBa did not differ between treatments (Fig. 5B). This further suggests that hepatic IKKB is not activated after prolonged IH administration. We found that hepatic mRNA levels of $I l 6(\mathrm{IH}=0.97 \pm 0.55$-fold of saline group (normalized control)) or of $\operatorname{Tnf}(\mathrm{IH}=1.05 \pm 0.39$-fold of saline group) were not altered after prolonged $\mathrm{IH}$ administration.

We also determined serine 307 phosphorylation of IRS-1, which is an established ex vivo marker of insulin resistance. We did not find any differences in serine 307-phosphorylated IRS-1 divided by total IRS-1 (Fig. 6). Total IRS-1 was also not affected. This suggests that this is not a primary site of hepatic insulin resistance caused by prolonged FFA elevation. Next, we assessed serine 473 Akt phosphorylation in the liver. IH decreased serine 473 phosphorylation of Akt, thereby indicating IH-induced impairment of insulin signaling. However, SS co-infusion completely prevented the IH-induced reduction in phosphorylation of Akt (Fig. 7A), and, moreover, SS alone increased phosphorylation of Akt

Table 1 Plasma glucose, FFA, and insulin concentrations during the basal and clamp periods after prolonged ( $48 \mathrm{~h}$ ) treatment in Wistar rats

\begin{tabular}{|c|c|c|c|c|c|c|c|c|}
\hline & \multicolumn{4}{|c|}{ Basal period } & \multicolumn{4}{|c|}{ Clamp period } \\
\hline & SAL & IH & $\mathrm{IH}+\mathrm{SS}$ & SS & SAL & $\mathrm{IH}$ & $\mathrm{IH}+\mathrm{SS}$ & SS \\
\hline $\begin{array}{l}\text { Glucose }(\mathrm{mmol} / \mathrm{l}) \\
\text { FFA }(\mu \mathrm{Eq} / \mathrm{l}) \\
\text { Insulin }(\mathrm{pM})\end{array}$ & $\begin{array}{c}6.42 \pm 0.19 \\
545 \pm 30 \\
68 \pm 11\end{array}$ & $\begin{array}{c}6.09 \pm 0.22 \\
876 \pm 55^{*,+} \\
111 \pm 19^{\ddagger, \dagger}\end{array}$ & $\begin{array}{c}6.28 \pm 0.13 \\
909 \pm 99 * \cdot+ \\
43 \pm 5\end{array}$ & $\begin{array}{c}6.37 \pm 0.07 \\
525 \pm 52 \\
31 \pm 6\end{array}$ & $\begin{array}{c}6.49 \pm 0.17 \\
157 \pm 48 \\
579 \pm 20\end{array}$ & $\begin{array}{l}6.28 \pm 0.15 \\
491 \pm 43^{*}+ \\
608 \pm 49\end{array}$ & $\begin{array}{l}6.29 \pm 0.14 \\
538 \pm 50^{*}+ \\
563 \pm 12\end{array}$ & $\begin{array}{l}6.41 \pm 0.13 \\
158 \pm 26 \\
594 \pm 41\end{array}$ \\
\hline
\end{tabular}

Treatments: SAL, saline $(5.5 \mu \mathrm{l} / \mathrm{min}) ; \mathrm{IH}$, Intralipid plus heparin ( $20 \%$ Intralipid plus $20 \mathrm{U} / \mathrm{ml}$ heparin at $5.5 \mu \mathrm{l} / \mathrm{min})$; IH $+\mathrm{SS}$, Intralipid plus heparin co-infused with sodium salicylate $(7 \mathrm{mg} / \mathrm{kg}$ bolus plus $0.117 \mathrm{mg} / \mathrm{kg}$ per $\mathrm{min})$; SS, sodium salicylate alone. $n=9-14 /$ group. ${ }^{*} P<0.05$ vs SAL. ${ }^{\dagger} P<0.05$ vs SS. ${ }^{\ddagger} P<0.05$ vs IH + SS.

http://joe.endocrinology-journals.org DOI: 10.1530/JOE-12-0214
C 2013 Society for Endocrinology Printed in Great Britain
Published by Bioscientifica Ltd 

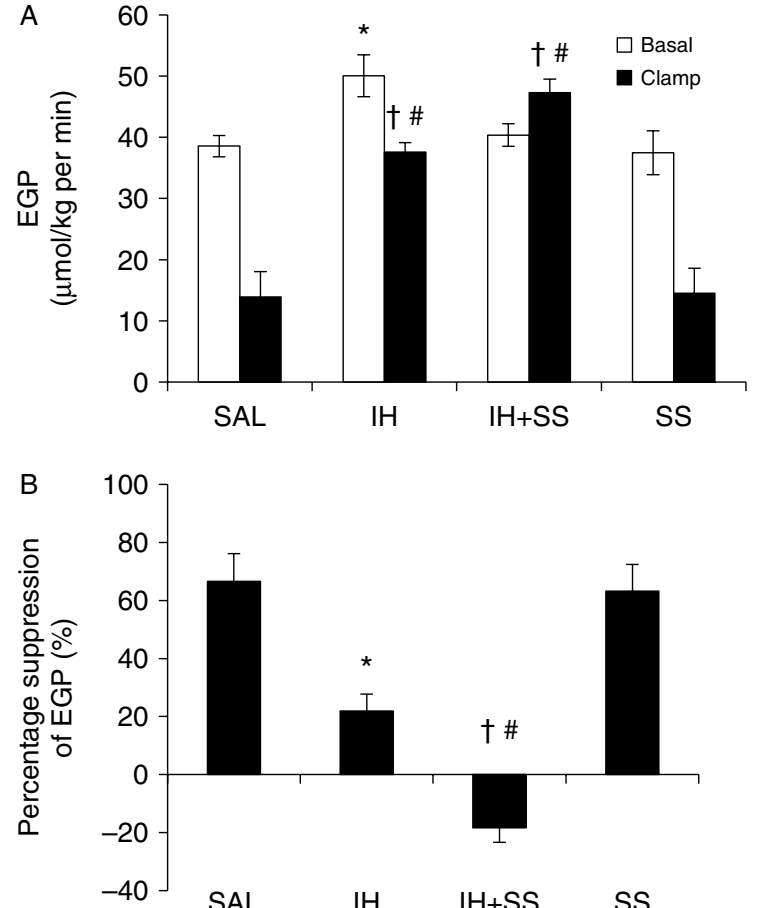

Figure 1

EGP in the prolonged ( $48 \mathrm{~h}$ ) infusion model in Wistar rats. (A) EGP during the basal period ( $30 \mathrm{~min}$ immediately before the hyperinsulinemic euglycemic clamp) and the clamp period (last $30 \mathrm{~min}$ of the hyperinsulinemic euglycemic clamp). (B) Percent suppression in EGP in the clamp period compared with the basal period. Treatments: SAL, saline $(5.5 \mu \mathrm{l} / \mathrm{min}) ; \mathrm{IH}$, Intralipid plus heparin (20\% Intralipid plus $20 \mathrm{U} / \mathrm{ml}$ heparin at $5.5 \mu \mathrm{l} / \mathrm{min}) ; \mathrm{IH}+\mathrm{SS}$, Intralipid plus heparin co-infused with sodium salicylate (7 mg/kg bolus plus $0.117 \mathrm{mg} / \mathrm{kg}$ per $\mathrm{min}) ; \mathrm{SS}$, sodium salicylate alone. $n=9-14 /$ group. Data were analyzed by one-way ANOVA followed by Tukey's test. ${ }^{*} P<0.05$ vs other groups. ${ }^{\dagger} P<0.05$ vs SAL. ${ }^{\#} P<0.05$ vs SS

$(P<0.05$ vs saline, Fig. 7A). These results suggest that i) after $48 \mathrm{~h}$ of IH infusion, there is a disconnect in hepatic insulin resistance assessed in vivo vs ex vivo (liver) and ii) after $48 \mathrm{~h}$ of SS treatment, SS itself increases hepatic Akt activation. To further explore the mechanism of the latter observation, we determined plasma adiponectin because in high-fat-diet-fed mice SS administration augments adiponectin gene expression in adipose tissue (Nixon et al. 2012) and adiponectin can stimulate Akt activation (Ouchi et al. 2004, Yamauchi et al. 2007). Indeed, we found that plasma adiponectin levels were higher in the co-infusion group compared with the saline and IH groups $(P<0.05$, Fig. $7 \mathrm{~B})$; plasma adiponectin levels in the SS alone group were intermediate, between the levels in the co-infusion group and the saline or $\mathrm{IH}$ groups (Fig. 7B).
PKC- $\delta$ impairs insulin signaling, but it does not phosphorylate IRS-1 at serine 307 directly (Greene et al. 2004), and by activating p38 MAPK, PKC- $\delta$ can increase gluconeogenic enzyme mRNA independent of Akt (Collins et al. 2006). We have previously reported that short-term $(7 \mathrm{~h}) \mathrm{IH}$ infusion activates PKC- $\delta$ in the liver, based on its translocation from cytosol to membrane (Lam et al. 2002). Here, we show that prolonged (48 h) IH infusion also activates PKC- $\delta$ in the liver and addition of SS did not prevent this effect (Fig. 8). Furthermore, the mRNA levels of the gluconeogenic enzyme Pck1 were over twofold greater in both the IH and IH plus SS groups compared with the saline group, but statistical significance was not reached across treatments $(2.99 \pm 1.14$-fold of saline in IH group vs $2.39 \pm 0.87$ in IH plus SS group vs $1.14 \pm 0.22$ in SS alone group).
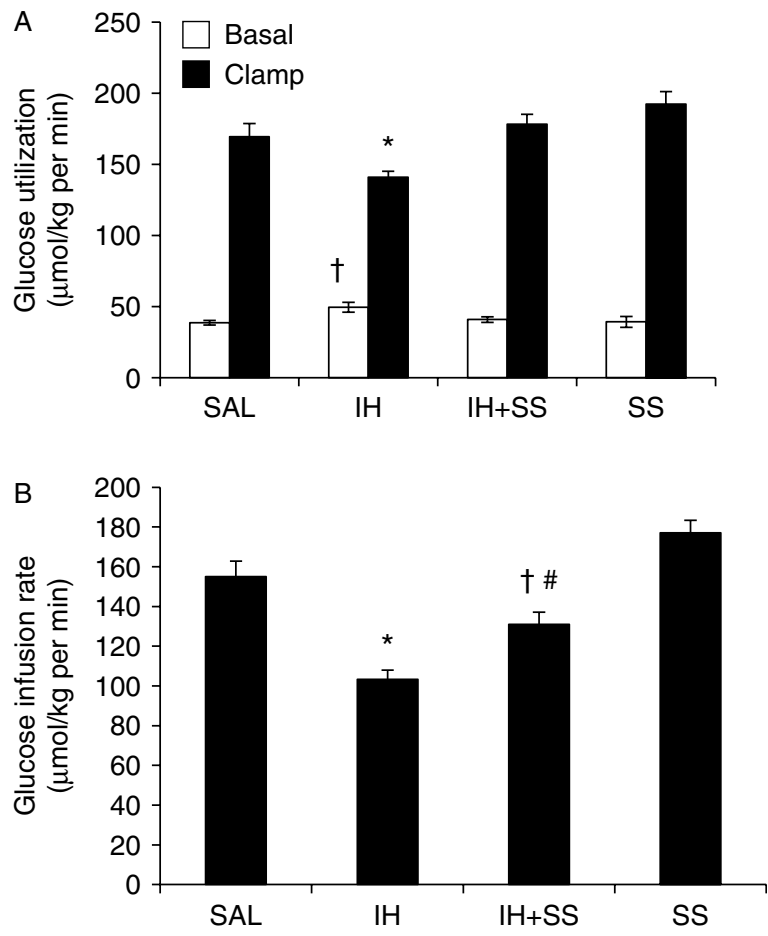

Figure 2

Glucose utilization and glucose infusion rate in the prolonged (48 h) infusion model in Wistar rats. (A) Glucose utilization during basal period (30 min immediately before the hyperinsulinemic euglycemic clamp) and clamp period (last $30 \mathrm{~min}$ of the hyperinsulinemic euglycemic clamp).

(B) Glucose infusion rate during the clamp period. Treatments: SAL, saline $(5.5 \mu \mathrm{l} / \mathrm{min}) ; \mathrm{IH}$, Intralipid plus heparin $(20 \%$ Intralipid plus $20 \mathrm{U} / \mathrm{ml}$ heparin at $5.5 \mu \mathrm{l} / \mathrm{min}) ; \mathrm{IH}+\mathrm{SS}$, Intralipid plus heparin co-infused with sodium salicylate ( $7 \mathrm{mg} / \mathrm{kg}$ bolus plus $0.117 \mathrm{mg} / \mathrm{kg}$ per $\mathrm{min})$; $\mathrm{SS}$, sodium salicylate alone. $n=9-14 /$ group. Data were analyzed by one-way ANOVA followed by Tukey's test. ${ }^{*} P<0.05$ vs other groups. ${ }^{\dagger} P<0.05$ vs SAL. ${ }^{\#} P<0.05$ vs SS.

Published by Bioscientifica Ltd 


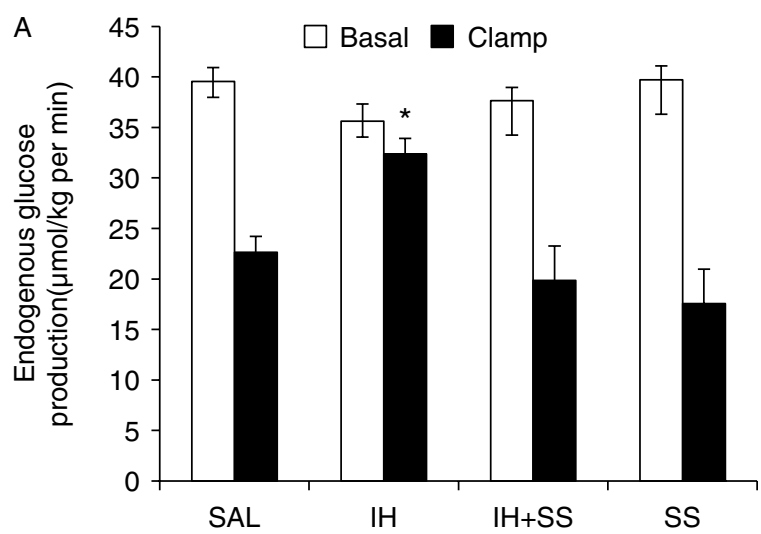

B

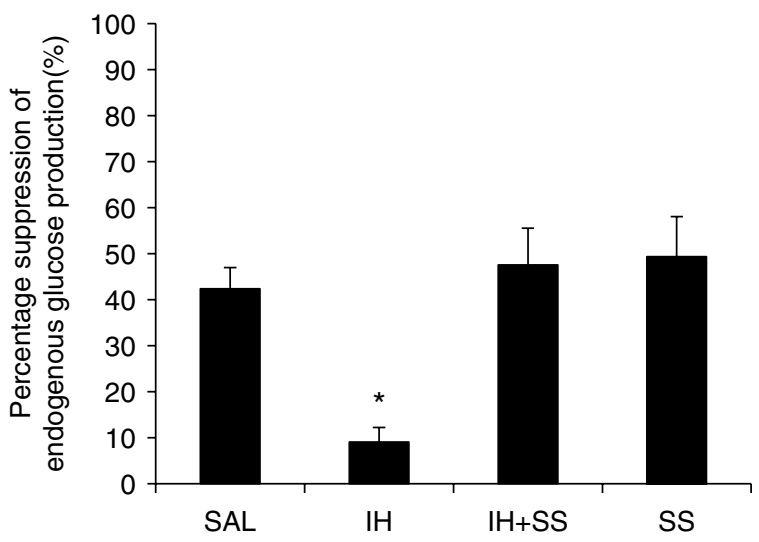

Figure 3

EGP in the short-term (7 h) infusion model in Wistar rats. (A) EGP during the basal period (30 min immediately before the hyperinsulinemic euglycemic clamp) and the clamp period (last $30 \mathrm{~min}$ of the hyperinsulinemic euglycemic clamp). (B) Percent suppression in EGP in the clamp period compared with the basal period. Treatments: SAL, saline $(5.5 \mu \mathrm{l} / \mathrm{min}) ; \mathrm{IH}$, Intralipid plus heparin ( $20 \%$ Intralipid plus $20 \mathrm{U} / \mathrm{ml}$ heparin at $5.5 \mu \mathrm{l} / \mathrm{min})$; $\mathrm{IH}+\mathrm{SS}$, Intralipid plus heparin co-infused with sodium salicylate $(7 \mathrm{mg} / \mathrm{kg}$ bolus plus $0.117 \mathrm{mg} / \mathrm{kg}$ per $\mathrm{min}$ ); SS, sodium salicylate alone. $n=3-6 / \mathrm{group}$. Data were analyzed by one-way ANOVA followed by Tukey's test. $* P<0.05$ vs other groups.

In skeletal muscle, although IkBa protein levels were not altered after prolonged IH administration (Fig. 9A), IkBa phosphorylation was augmented and the effect of IH was prevented by SS ( $P<0.05$ vs other groups, Fig. $9 \mathrm{~B})$. Although phosphorylation of serine 307 IRS-1 in skeletal muscle tended to be increased after prolonged $\mathrm{IH}$ administration, the difference was not significant (Fig. 10) and addition of SS did not reverse this tendency.

\section{Discussion}

In the current study, we show that hepatic insulin resistance caused by prolonged FFA elevation is not associated with IKKB activation in the liver and, accordingly, it is not prevented by SS. We also found that hepatic serine 307 of IRS- 1 is not a target for phosphorylation by IKKB or other serine/threonine kinases in the liver in response to prolonged lipid infusion. Lastly, we found that prolonged FFA elevation causes peripheral insulin resistance and activates IKKB in skeletal muscle, both of which are prevented by SS.

Our findings are in contrast to the findings that liverspecific IKKB KO mice on a high-fat diet show improved, albeit not normalized, in vivo hepatic insulin sensitivity relative to controls fed a high-fat diet (Arkan et al. 2005). It is possible that in the high-fat diet model, cytokines rather than fat are the main inducers of IKKB activation,
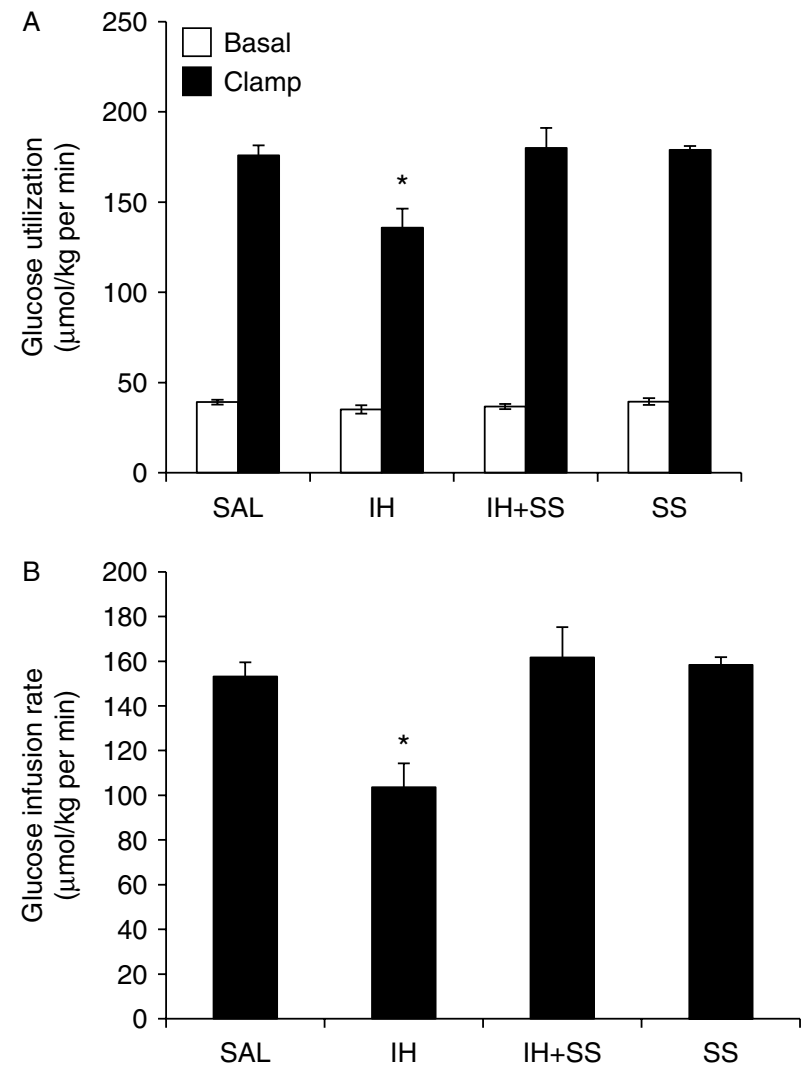

Figure 4

Glucose utilization and glucose infusion rate in the short-term $(7 \mathrm{~h})$ infusion model in Wistar rats. (A) Glucose utilization during basal period (30 min immediately before the hyperinsulinemic euglycemic clamp) and clamp period (last $30 \mathrm{~min}$ of the hyperinsulinemic euglycemic clamp). (B) Glucose infusion rate during the clamp period. Treatments: SAL, saline $(5.5 \mu \mathrm{l} / \mathrm{min}) ; \mathrm{IH}$, Intralipid plus heparin $(20 \%$ Intralipid plus $20 \mathrm{U} / \mathrm{ml}$ heparin at $5.5 \mu \mathrm{l} / \mathrm{min}$ ); $\mathrm{IH}+\mathrm{SS}$, Intralipid plus heparin co-infused with sodium salicylate ( $7 \mathrm{mg} / \mathrm{kg}$ bolus plus $0.117 \mathrm{mg} / \mathrm{kg}$ per $\mathrm{min}$ ); SS, sodium salicylate alone. $n=3-6 /$ group. Data were analyzed by one-way ANOVA followed by Tukey's test. ${ }^{*} P<0.05$ vs other groups.

Published by Bioscientifica Ltd. 

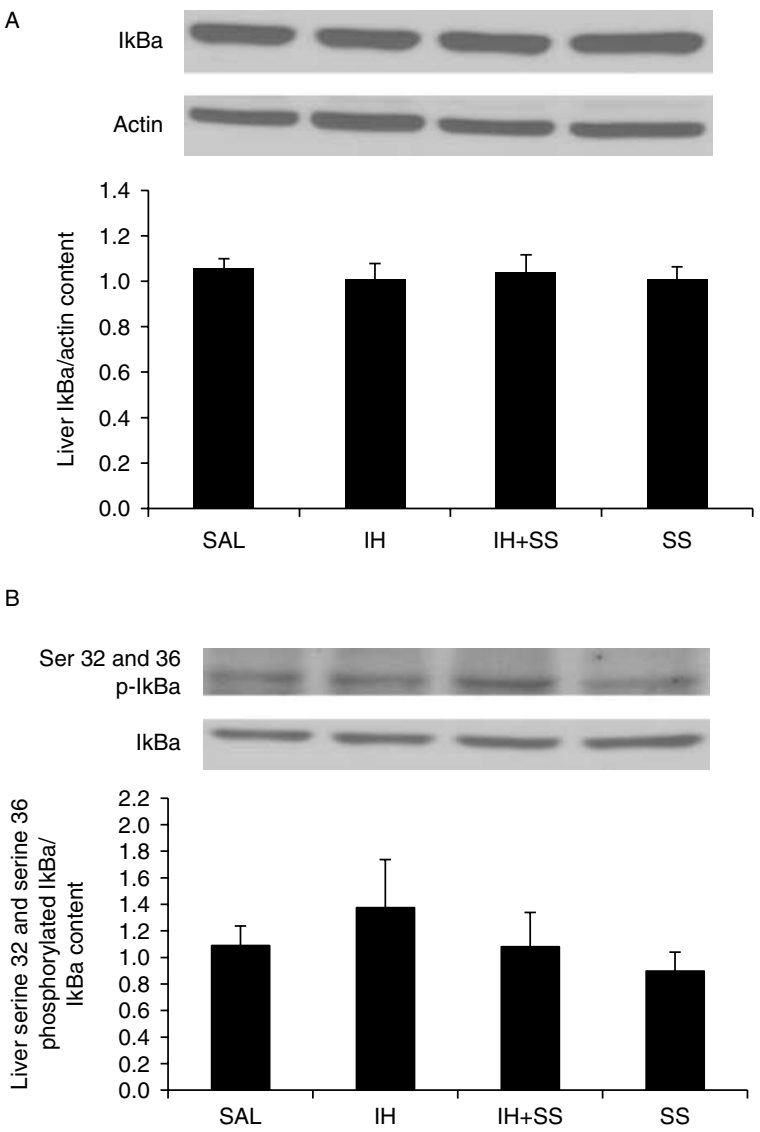

Figure 5

Hepatic phosphorylated IkBa and IkBa protein levels after $48 \mathrm{~h}$ of treatment, at the end of the hyperinsulinemic euglycemic clamp, in Wistar rats. (A) Hepatic IkBa protein content divided by actin protein content. (B) Hepatic serine 32 and serine 36-phosphorylated IkBa protein content divided by IkBa protein content. Treatments: SAL, saline $(5.5 \mu \mathrm{l} / \mathrm{min})$; $\mathrm{IH}$, Intralipid plus heparin (20\% Intralipid plus $20 \mathrm{U} / \mathrm{ml}$ heparin at $5.5 \mu \mathrm{l} / \mathrm{min}$ ); $\mathrm{IH}+\mathrm{SS}$, Intralipid plus heparin co-infused with sodium salicylate $(7 \mathrm{mg} / \mathrm{kg}$ bolus plus $0.117 \mathrm{mg} / \mathrm{kg}$ per $\mathrm{min}$ ); SS, sodium salicylate alone. $n=5-6 /$ group. Data were analyzed by one-way ANOVA followed by Tukey's test.

unlike our model where we found that prolonged $\mathrm{IH}$ administration did not alter hepatic expression of $I l 6$ and Tnf. Interestingly, in a model of cytokine-induced glucose intolerance, liver-specific IKKB KO mice showed better glucose tolerance than controls (Arkan et al. 2005). Our results, however, do agree with studies on T2DM subjects, where treatment with high-dose aspirin improved peripheral insulin sensitivity but failed to improve insulin action on EGP (Hundal et al. 2002). Indeed, we have also found that prolonged infusion of olive oil $(48 \mathrm{~h})$ in rats induces hepatic insulin resistance that is not prevented by SS coinfusion (Park et al. 2005).

Our current results, together with our other previously published results (Park et al. 2007), suggest that IKKB is causal in fat-induced hepatic insulin resistance in the short term, but IKKB does not mediate hepatic insulin resistance due to prolonged FFA elevation. In terms of markers of hepatic IKKB activation, we did not find that either total IkBa or phosphorylated IkBa normalized by total IkBa was altered by prolonged lipid infusion. By contrast, we previously found that short-term lipid infusion decreases total IkBa and this is prevented by SS co-infusion (Park et al. 2007). It is possible that as the length of lipid infusion increases from 7 to $48 \mathrm{~h}$, the negative feedback loop whereby NF-kB increases IkBa gene expression (Sun et al. 1993) takes effect. This feedback loop, however, does not explain the lack of effect of prolonged lipid infusion on IkBa phosphorylation, suggesting mechanisms of IKKB inactivation with prolonged duration of lipid infusion.

Consistent with the lack of increased IkBa phosphorylation, serine 307 of IRS- 1 does not show changes in phosphorylation in the liver across treatments, suggesting that IKKB is not activated and that this is not a source of hepatic insulin resistance caused by prolonged lipid infusion. Our results also suggest that other kinases that target serine 307 in IRS-1, such as c-jun $\mathrm{NH}_{2}$ terminal kinase (JNK; Aguirre et al. 2000), are likely not involved in hepatic insulin resistance after prolonged lipid infusion. Nevertheless, impairments at the level of IRS proteins may still exist because of phosphorylation of other

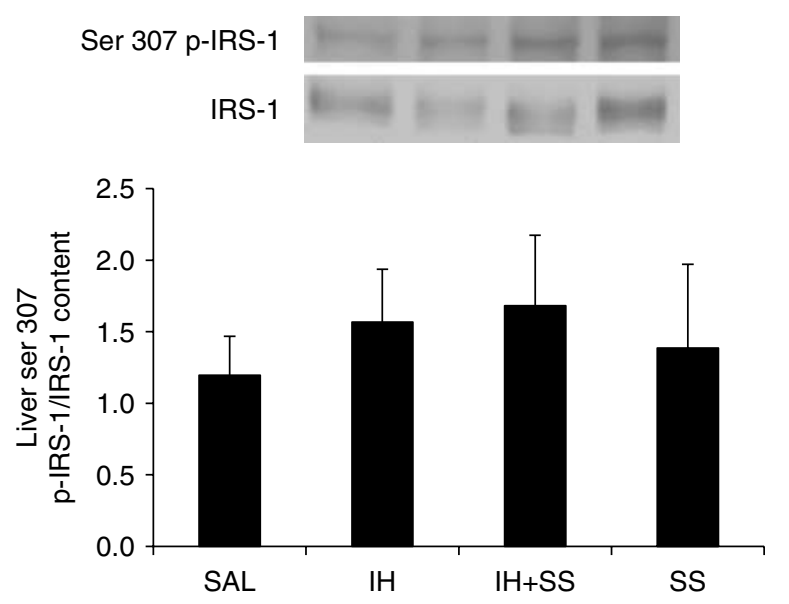

Figure 6

Hepatic serine 307-phosphorylated IRS-1 (Ser 307 p-IRS-1) protein content divided by IRS- 1 protein content after $48 \mathrm{~h}$ of treatment, at the end of the hyperinsulinemic euglycemic clamp, in Wistar rats. Treatments: SAL, saline (5.5 $\mu \mathrm{l} / \mathrm{min}) ; \mathrm{IH}$, Intralipid plus heparin ( $20 \%$ Intralipid plus $20 \mathrm{U} / \mathrm{ml}$ heparin at $5.5 \mu \mathrm{l} / \mathrm{min}) ; \mathrm{IH}+\mathrm{SS}$, Intralipid plus heparin co-infused with sodium salicylate ( $7 \mathrm{mg} / \mathrm{kg}$ bolus plus $0.117 \mathrm{mg} / \mathrm{kg}$ per $\mathrm{min}$ ); SS, sodium salicylate alone. $n=6 /$ group. Data were analyzed by one-way ANOVA followed by Tukey's test.

Published by Bioscientifica Ltd. 
A
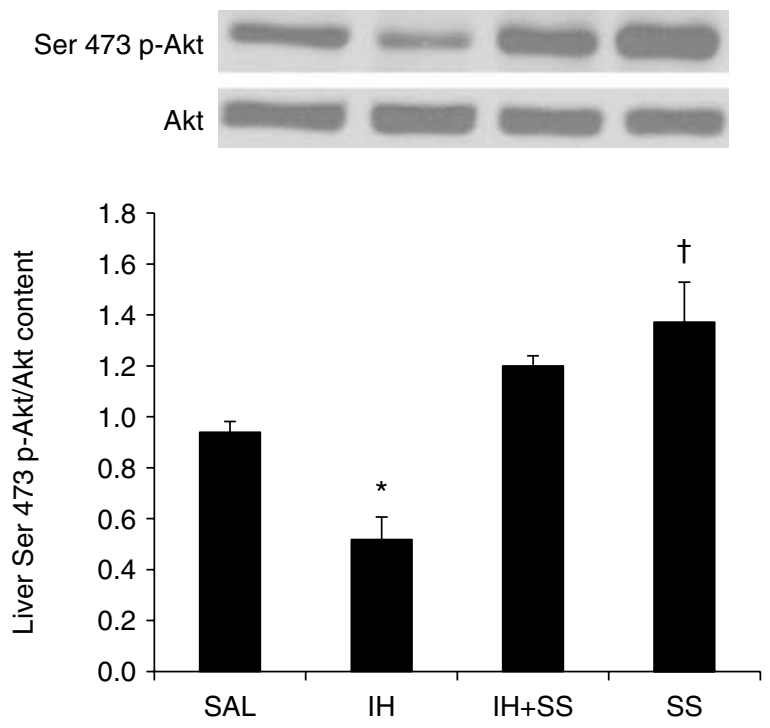

B

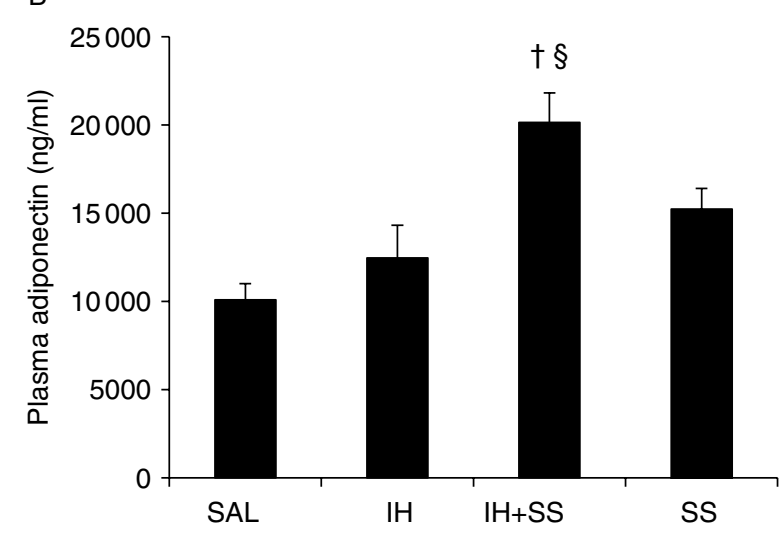

Figure 7

(A) Hepatic serine 473-phosphorylated Akt (Ser 473 p-Akt) protein content divided by Akt protein content, after $48 \mathrm{~h}$ of treatment, at the end of the hyperinsulinemic euglycemic clamp, in Wistar rats. $n=4-6 /$ group. (B) Plasma adiponectin concentrations during the basal period (30 min period immediately before the hyperinsulinemic euglycemic clamp) in the prolonged $(48 \mathrm{~h}$ ) infusion model in Wistar rats. $n=8-14 /$ group. Treatments: $\mathrm{SAL}$, saline $(5.5 \mu \mathrm{l} / \mathrm{min})$; IH, Intralipid plus heparin ( $20 \%$ Intralipid plus $20 \mathrm{U} / \mathrm{ml}$ heparin at $5.5 \mu \mathrm{l} / \mathrm{min}) ; \mathrm{IH}+\mathrm{SS}$, Intralipid plus heparin co-infused with sodium salicylate ( $7 \mathrm{mg} / \mathrm{kg}$ bolus plus $0.117 \mathrm{mg} / \mathrm{kg}$ per $\mathrm{min}$ ); SS, sodium salicylate alone. Data were analyzed by one-way ANOVA followed by Tukey's test. ${ }^{\star} P<0.05$ vs other groups. ${ }^{\dagger} P<0.05$ vs SAL. ${ }^{\S} P<0.05$ vs IH.

serine/threonine residues and/or impairment of tyrosine phosphorylation. A novel PKC isoform, PKC- $\varepsilon$, binds to the insulin receptor in the liver in vivo and it can diminish the receptor's kinase activity, thereby inducing hepatic insulin resistance after a 3-day high-fat diet (Samuel et al. 2007). We (Lam et al. 2002) and others (Boden et al. 2005) have reported that hepatic insulin resistance due to short-term lipid infusion is associated with membrane translocation (marker of activation) of another novel PKC isoform, PKC- $\delta$, in the liver, and, interestingly, PKC- $\delta$ does not directly phosphorylate IRS- 1 at serine 307 (Greene et al. 2004). We herein found that PKC- $\delta$ membrane translocation is increased by IH and not affected by SS, which raises the possibility that hepatic insulin resistance in the prolonged IH infusion model may be mediated by PKC- $\delta$, although this should be tested in future inhibition studies. PKC- $\delta$ could act by reducing tyrosine phosphorylation of IRS-1 (Greene et al. 2004), which should still affect Akt, or via p38 MAPK, which would directly affect gluconeogenic enzyme gene expression (Collins et al. 2006). P38 MAPK can also be activated by insulin (Fujishiro et al. 2001), and, therefore, our liver samples obtained after a hyperinsulinemic euglycemic clamp are not adequate for assessment of its activation. Our preliminary data suggest that short-term $\mathrm{IH}$ infusion in the absence of hyperinsulinemic clamp increases phosphorylation of p38 MAPK in the liver (data not shown).

Unexpectedly, salicylate, which did not affect IH-induced hepatic insulin resistance, normalized hepatic phosphorylation of Akt. The reduced Akt phosphorylation

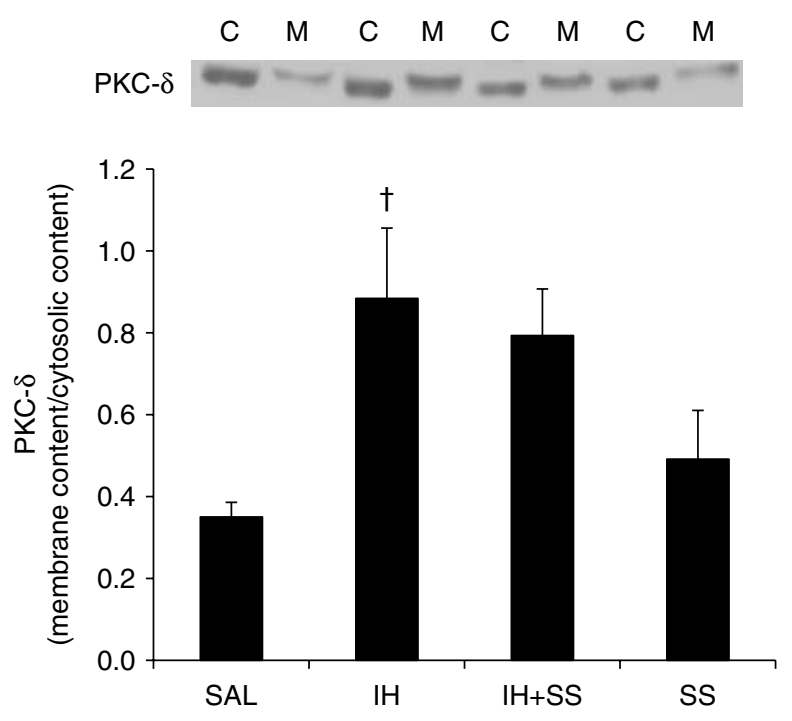

Figure 8

Membrane PKC- $\delta$ protein content (M) divided by cytosolic PKC-delta protein content $(\mathrm{C})$, after $48 \mathrm{~h}$ of treatment, at the end of the hyperinsulinemic euglycemic clamp, in Wistar rats. Treatments: SAL, saline (5.5 $\mu \mathrm{l} / \mathrm{min}) ; \mathrm{IH}$, Intralipid plus heparin ( $20 \%$ Intralipid plus $20 \mathrm{U} / \mathrm{ml}$ heparin at $5.5 \mu \mathrm{l} / \mathrm{min}) ; \mathrm{IH}+\mathrm{SS}$, Intralipid plus heparin co-infused with sodium salicylate ( $7 \mathrm{mg} / \mathrm{kg}$ bolus plus $0.117 \mathrm{mg} / \mathrm{kg}$ per $\mathrm{min}$ ). $n=4-6 /$ group. Data were analyzed by one-way ANOVA followed by Tukey's test. ${ }^{\dagger} P<0.05$ vs SAL. 
A
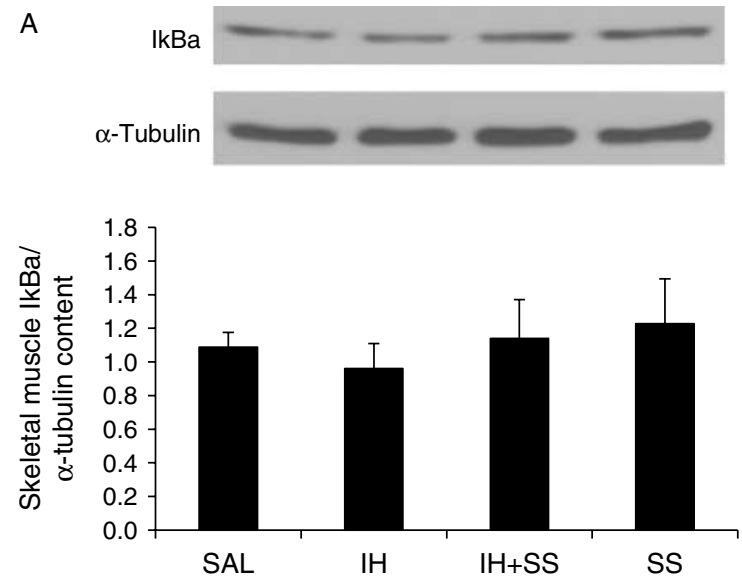

B
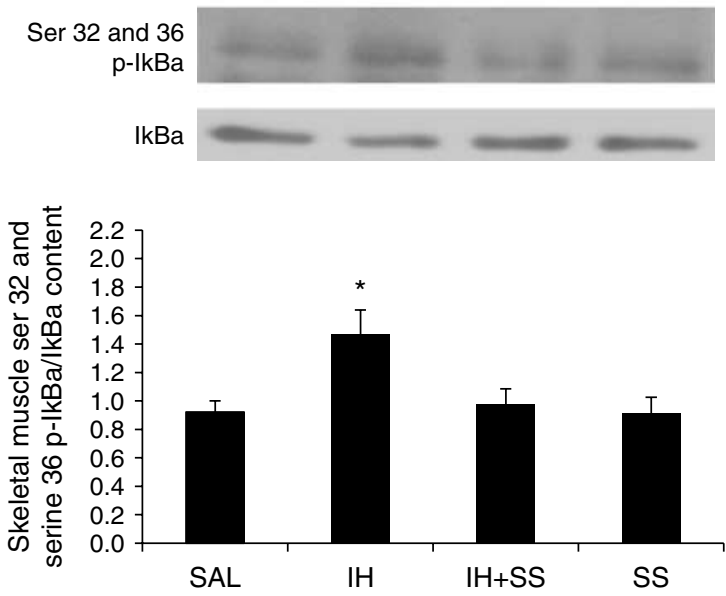

Figure 9

Skeletal muscle phosphorylated IkBa ( $\mathrm{p}-\mathrm{lkBa}$ ) and IkBa protein levels after $48 \mathrm{~h}$ of treatment, at the end of the hyperinsulinemic euglycemic clamp, in Wistar rats. (A) Skeletal muscle IkBa protein content divided by $\alpha$-tubulin protein content. (B) Skeletal muscle serine (Ser) 32- and Ser 36-phosphorylated IkBa protein content divided by IkBa protein content. Treatments: SAL, saline $(5.5 \mu \mathrm{l} / \mathrm{min}) ; \mathrm{IH}$, Intralipid plus heparin $(20 \%$ Intralipid plus $20 \mathrm{U} / \mathrm{ml}$ heparin at $5.5 \mu \mathrm{l} / \mathrm{min}$ ); $\mathrm{IH}+\mathrm{SS}$, Intralipid plus heparin co-infused with sodium salicylate ( $7 \mathrm{mg} / \mathrm{kg}$ bolus plus $0.117 \mathrm{mg} / \mathrm{kg}$ per $\mathrm{min}$ ); SS, sodium salicylate alone. $n=5-6 / g r o u p$. Data were analyzed by one-way ANOVA followed by Tukey's test. $* P<0.05$ vs other groups.

caused by prolonged IH infusion could be mediated by ceramides (Schmitz-Peiffer et al. 1999) or the protein phosphatase and tensin homolog deleted on chromosome 10 (PTEN), which is stabilized by p38 MAPK (Liu et al. 2007). The IH-induced Akt inhibition was prevented by SS co-infusion in association with increased plasma concentrations of adiponectin. It has been documented that SS increases mRNA levels of adiponectin in adipose tissue by a mechanism that may not be IKKB related (Nixon et al. 2012) (an IKKB-independent mechanism would be in accordance with our data in the 7-h IH infusion model, where we could not find an increase in markers of IKKB activation in adipose tissue (Park et al. 2007)). In obese subjects, treatment with salsalate, a salicylate dimer, elevated circulating adiponectin concentrations (Fleischman et al. 2008). Moreover, adiponectin increases Akt activation, for instance via increased ceramidase activity (Schmitz-Peiffer et al. 1999, Holland et al. 2011). Hepatic levels of Akt phosphorylation did not correlate with in vivo-determined hepatic insulin sensitivity, which raises the possibility that hepatic insulin resistance caused by prolonged IH infusion may be due to the counteraction of insulin's effects on gluconeogenic enzyme gene expression rather than impairment in insulin signaling. In fact, the mRNA levels of $P c k 1$ were in accordance with in vivo-determined hepatic glucose production. The effect of IH on Pck1 mRNA could be via counteraction of insulin's effects on gluconeogenic enzyme gene expression, via the PKC- $\delta /$ p38 MAPK axis.

While it is likely that prolonged IH infusion induced insulin resistance directly on the liver, an indirect effect mediated in the CNS is another possibility. Thus, insulinstimulated suppression of EGP can be impaired in the context of normal insulin signaling in the liver when insulin signaling in the hypothalamus is reduced (Okamoto et al. 2005). Fat at the level of the brain induces central insulin resistance (Posey et al. 2009) as

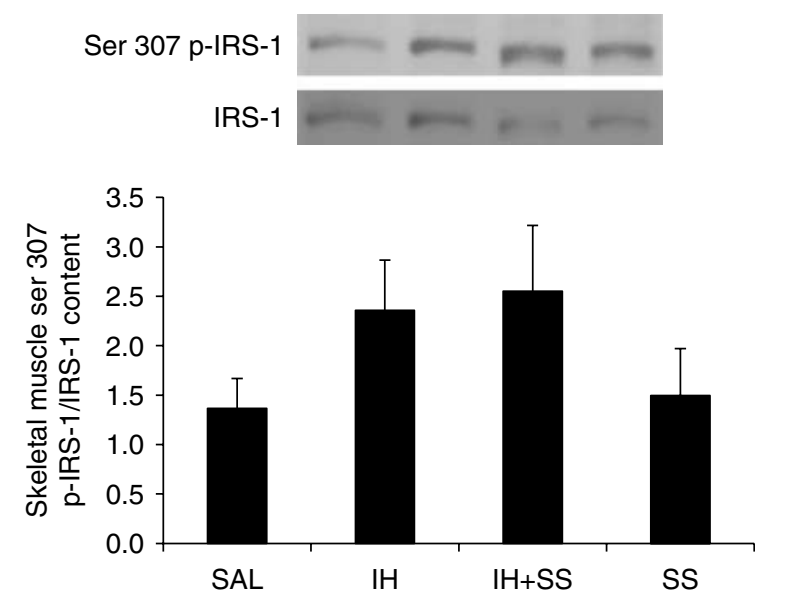

Figure 10

Skeletal muscle serine 307-phosphorylated IRS-1 (Ser 307 p-IRS-1) protein content divided by IRS-1 protein content after $48 \mathrm{~h}$ of treatment, at the end of the hyperinsulinemic euglycemic clamp, in Wistar rats. Treatments: SAL, saline $(5.5 \mu \mathrm{l} / \mathrm{min}) ; \mathrm{IH}$, Intralipid plus heparin (20\% Intralipid plus $20 \mathrm{U} / \mathrm{ml}$ heparin at $5.5 \mu \mathrm{l} / \mathrm{min}) ; \mathrm{IH}+\mathrm{SS}$, Intralipid plus heparin co-infused with sodium salicylate ( $7 \mathrm{mg} / \mathrm{kg}$ bolus plus $0.117 \mathrm{mg} / \mathrm{kg}$ per $\mathrm{min}$ ); SS, sodium salicylate alone. $n=6 /$ group. Data were analyzed by one-way ANOVA followed by Tukey's test.

Published by Bioscientifica Ltd. 
well as hepatic insulin resistance evaluated with a hyperinsulinemic euglycemic clamp (Clement et al. 2002, Benoit et al. 2009). Insulin acting in the brain suppresses EGP, and this brain-liver circuit appears to be independent of hepatic Akt activation (Inoue et al. 2006, Myers 2006). At the level of the liver, central insulin suppresses hepatic glucose production through hepatic IL6 production, which in turn activates STAT3, a transcription factor that decreases the expression of gluconeogenic genes (Inoue et al. 2006, Myers 2006). Hepatic Il6 mRNA levels were not affected by IH in our model, which makes the importance of this brain-liver circuit less likely. Furthermore, although i.c.v. palmitate administration can result in hypothalamic IKKB activation (Posey et al. 2009) and adenoviral delivery of constitutively active IKKB into the hypothalamus induces hypothalamic insulin resistance (Zhang et al. 2008), it is unlikely that IKKB activation in the brain causes hepatic insulin resistance in our prolonged lipid infusion model because SS, which can cross the blood-brain barrier (Su et al. 2009), was ineffective in preventing hepatic insulin resistance.

Prolonged plasma FFA elevation stimulated IkBa phosphorylation, a marker of IKKB activation, in skeletal muscle and this was prevented by SS co-infusion. However, prolonged plasma FFA elevation did not significantly increase phosphorylation of IRS-1 at serine 307 . As previously mentioned, serine 307 of IRS- 1 is a target of IKKB, but addition of SS did not abolish the tendency of IRS-1 serine 307 phosphorylation to increase. The improvement observed in IH-induced peripheral insulin resistance when SS was co-infused may have been due to transcriptional effects of NF-kB activation rather than the effect of SS on IKKB. Another possibility to explain the SS effect in muscle is a beneficial effect of adiponectin on glucose uptake. This could be mediated via AMP-activated protein kinase (AMPK; Bruce et al. 2005), and interestingly, salicylate has been reported to directly activate AMPK (Hawley et al. 2012).

Our results suggest that as the duration of FFA elevation increases, the IKKB pathway in the liver becomes inactivated. This study also suggests that normalization of Akt phosphorylation is not sufficient to normalize hepatic insulin sensitivity after prolonged plasma FFA elevation, raising the possibility that prevention of FFA effect on gluconeogenic enzyme expression may also be required, perhaps by inhibiting the PKC- $\delta / \mathrm{p} 38$ MAPK axis. We conclude that hepatic insulin resistance caused by prolonged FFA elevation is mediated by factors that do not target serine 307 of IRS- 1 and remain to be identified, but PKC- $\delta$ is a plausible candidate.

\section{Declaration of interest}

The authors declare that there is no conflict of interest that could be perceived as prejudicing the impartiality of the research reported.

\section{Funding}

Research grants from Canadian Institutes of Health Research (CIHR) (MOP-89929) and Canadian Diabetes Association (GA-02-06-2131-AG) to A G and in part from CIHR (MOP-97979) to I G F funded this study. S P was funded by a Canada Graduate Scholarships Doctoral Award from CIHR, Ontario Graduate Scholarship and Banting and Best Diabetes Centre/Novo Nordisk Studentship. M E F was funded by a postdoctoral fellowship from the National Council of Science and Technology (CONACYT), Mexico.

\section{Acknowledgements}

The authors thank Loretta Lam for outstanding technical support.

\section{References}

Aguirre V, Uchida T, Yenush L, Davis R \& White MF 2000 The c-Jun NH(2)terminal kinase promotes insulin resistance during association with insulin receptor substrate-1 and phosphorylation of Ser(307). Journal of Biological Chemistry 275 9047-9054. (doi:10.1074/jbc.275.12.9047)

Arkan MC, Hevener AL, Greten FR, Maeda S, Li ZW, Long JM, Wynshaw-Boris A, Poli G, Olefsky J \& Karin M 2005 IKK- $\beta$ links inflammation to obesity-induced insulin resistance. Nature Medicine 11 191-198. (doi:10.1038/nm1185)

Barnes PJ \& Karin M 1997 Nuclear factor-кB: a pivotal transcription factor in chronic inflammatory diseases. New England Journal of Medicine 336 1066-1071. (doi:10.1056/NEJM199704103361506)

Benoit SC, Kemp CJ, Elias CF, Abplanalp W, Herman JP, Migrenne S, Lefevre AL, Cruciani-Guglielmacci C, Magnan C, Yu F et al. 2009 Palmitic acid mediates hypothalamic insulin resistance by altering PKC-theta subcellular localization in rodents. Journal of Clinical Investigation 119 2577-2589. (doi:10.1172/JCI36714)

Boden G 1997 Role of fatty acids in the pathogenesis of insulin resistance and NIDDM. Diabetes 46 3-10. (doi:10.2337/diabetes.46.1.3)

Boden G, She P, Mozzoli M, Cheung P, Gumireddy K, Reddy P, Xiang X, Luo Z \& Ruderman N 2005 Free fatty acids produce insulin resistance and activate the proinflammatory nuclear factor- $\kappa \mathrm{B}$ pathway in rat liver. Diabetes 54 3458-3465. (doi:10.2337/diabetes.54.12.3458)

Brown K, Gerstberger S, Carlson L, Franzoso G \& Siebenlist U 1995 Control of $\mathrm{I} \kappa \mathrm{B}-\alpha$ proteolysis by site-specific, signal-induced phosphorylation. Science 267 1485-1488. (doi:10.1126/science.7878466)

Bruce CR, Mertz VA, Heigenhauser GJ \& Dyck DJ 2005 The stimulatory effect of globular adiponectin on insulin-stimulated glucose uptake and fatty acid oxidation is impaired in skeletal muscle from obese subjects. Diabetes 54 3154-3160. (doi:10.2337/diabetes.54.11.3154)

Cai D, Yuan M, Frantz DF, Melendez PA, Hansen L, Lee J \& Shoelson SE 2005 Local and systemic insulin resistance resulting from hepatic activation of IKK- $\beta$ and NF-кB. Nature Medicine 11 183-190. (doi:10.1038/nm1166)

Clement L, Cruciani-Guglielmacci C, Magnan C, Vincent M, Douared L, Orosco M, Assimacopoulos-Jeannet F, Penicaud L \& Ktorza A 2002 Intracerebroventricular infusion of a triglyceride emulsion leads to both altered insulin secretion and hepatic glucose production in rats. 
Pflügers Archiv - European Journal of Physiology 445 375-380. (doi:10.1007/s00424-002-0937-3)

Collins QF, Xiong Y, Lupo EG Jr, Liu HY \& Cao W 2006 p38 Mitogenactivated protein kinase mediates free fatty acid-induced gluconeogenesis in hepatocytes. Journal of Biological Chemistry $28124336-24344$. (doi:10.1074/jbc.M602177200)

DiDonato JA, Mercurio F \& Karin M 1995 Phosphorylation of І $\kappa$ B $\alpha$ precedes but is not sufficient for its dissociation from NF-кB. Molecular and Cellular Biology 15 1302-1311.

Finegood DT, Bergman RN \& Vranic M 1987 Estimation of endogenous glucose production during hyperinsulinemic-euglycemic glucose clamps. Comparison of unlabeled and labeled exogenous glucose infusates. Diabetes 36 914-924. (doi:10.2337/diabetes.36.8.914)

Fleischman A, Shoelson SE, Bernier R \& Goldfine AB 2008 Salsalate improves glycemia and inflammatory parameters in obese young adults. Diabetes Care 31 289-294. (doi:10.2337/dc07-1338)

Fujishiro M, Gotoh Y, Katagiri H, Sakoda H, Ogihara T, Anai M, Onishi Y, Ono H, Funaki M, Inukai K et al. 2001 MKK6/3 and p38 MAPK pathway activation is not necessary for insulin-induced glucose uptake but regulates glucose transporter expression. Journal of Biological Chemistry 276 19800-19806. (doi:10.1074/jbc.M101087200)

Galic S, Oakhill JS \& Steinberg GR 2010 Adipose tissue as an endocrine organ. Molecular and Cellular Endocrinology 316 129-139. (doi:10.1016/j. mce.2009.08.018)

Gao Z, Hwang D, Bataille F, Lefevre M, York D, Quon MJ \& Ye J 2002 Serine phosphorylation of insulin receptor substrate 1 by inhibitor $\kappa \mathrm{B}$ kinase complex. Journal of Biological Chemistry 277 48115-48121. (doi:10.1074/jbc.M209459200)

Ghosh S \& Baltimore D 1990 Activation in vitro of NF-кB by phosphorylation of its inhibitor IкB. Nature $\mathbf{3 4 4} 678-682$. (doi:10.1038/344678a0)

Greene MW, Morrice N, Garofalo RS \& Roth RA 2004 Modulation of human insulin receptor substrate- 1 tyrosine phosphorylation by protein kinase Cdelta. Biochemical Journal 378 1-16. (doi:10.1042/BJ20031493)

Grund EM, Kagan D, Tran CA, Zeitvogel A, Starzinski-Powitz A, Nataraja S $\&$ Palmer SS 2008 Tumor necrosis factor- $\alpha$ regulates inflammatory and mesenchymal responses via mitogen-activated protein kinase kinase, p38, and nuclear factor $\kappa \mathrm{B}$ in human endometriotic epithelial cells. Molecular Pharmacology 73 1394-1404. (doi:10.1124/mol.107.042176)

Hacker H \& Karin M 2006 Regulation and function of IKK and IKK-related kinases. Science's STKE: Signal Transduction Knowledge Environment 2006 re13. (doi:10.1126/stke.3572006re13)

Hawley SA, Fullerton MD, Ross FA, Schertzer JD, Chevtzoff C, Walker KJ, Peggie MW, Zibrova D, Green KA, Mustard KJ et al. 2012 The ancient drug salicylate directly activates AMP-activated protein kinase. Science 336 918-922. (doi:10.1126/science.1215327)

Holland WL, Miller RA, Wang ZV, Sun K, Barth BM, Bui HH, Davis KE, Bikman BT, Halberg N, Rutkowski JM et al. 2011 Receptor-mediated activation of ceramidase activity initiates the pleiotropic actions of adiponectin. Nature Medicine 17 55-63. (doi:10.1038/nm.2277)

Hundal RS, Petersen KF, Mayerson AB, Randhawa PS, Inzucchi S, Shoelson SE \& Shulman GI 2002 Mechanism by which high-dose aspirin improves glucose metabolism in type 2 diabetes. Journal of Clinical Investigation 109 1321-1326. (doi:10.1172/JCI14955)

Inoue $\mathrm{H}$, Ogawa $\mathrm{W}$, Asakawa A, Okamoto Y, Nishizawa A, Matsumoto M, Teshigawara K, Matsuki Y, Watanabe E, Hiramatsu R et al. 2006 Role of hepatic STAT3 in brain-insulin action on hepatic glucose production. Cell Metabolism 3 267-275. (doi:10.1016/j.cmet.2006.02.009)

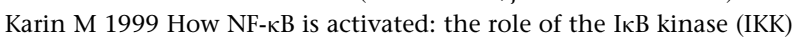
complex. Oncogene 18 6867-6874. (doi:10.1038/sj.onc.1203219)

Kim JK, Kim YJ, Fillmore JJ, Chen Y, Moore I, Lee J, Yuan M, Li ZW, Karin M, Perret P et al. 2001 Prevention of fat-induced insulin resistance by salicylate. Journal of Clinical Investigation 108 437-446. (doi:10.1172/ JCI11559)

Koska J, Ortega E, Bunt JC, Gasser A, Impson J, Hanson RL, Forbes J, de Courten B \& Krakoff J 2009 The effect of salsalate on insulin action and glucose tolerance in obese non-diabetic patients: results of a randomised double-blind placebo-controlled study. Diabetologia 52 385-393. (doi:10.1007/s00125-008-1239-x)

Lam TK, Yoshii H, Haber CA, Bogdanovic E, Lam L, Fantus IG \& Giacca A 2002 Free fatty acid-induced hepatic insulin resistance: a potential role for protein kinase C-delta. American Journal of Physiology. Endocrinology and Metabolism 283 E682-E691.

Lewis GF, Carpentier A, Adeli K \& Giacca A 2002 Disordered fat storage and mobilization in the pathogenesis of insulin resistance and type 2 diabetes. Endocrine Reviews 23 201-229. (doi:10.1210/er.23.2.201)

Liu HY, Collins QF, Xiong Y, Moukdar F, Lupo EG Jr, Liu Z \& Cao W 2007 Prolonged treatment of primary hepatocytes with oleate induces insulin resistance through p38 mitogen-activated protein kinase. Journal of Biological Chemistry 282 14205-14212. (doi:10.1074/jbc.M609701200)

Livak KJ \& Schmittgen TD 2001 Analysis of relative gene expression data using real-time quantitative PCR and the 2(-Delta DeltaC(T)) method. Methods 25 402-408.

Mason TM, Goh T, Tchipashvili V, Sandhu H, Gupta N, Lewis GF \& Giacca A 1999 Prolonged elevation of plasma free fatty acids desensitizes the insulin secretory response to glucose in vivo in rats. Diabetes 48 524-530. (doi:10.2337/diabetes.48.3.524)

Meex RC, Phielix E, Moonen-Kornips E, Schrauwen P \& Hesselink MK 2011 Stimulation of human whole-body energy expenditure by salsalate is fueled by higher lipid oxidation under fasting conditions and by higher oxidative glucose disposal under insulin-stimulated conditions. Journal of Clinical Endocrinology and Metabolism 96 1415-1423. (doi:10.1210/jc.2010-1816)

Mohlig M, Freudenberg M, Bobbert T, Ristow M, Rochlitz H, Weickert MO, Pfeiffer AF \& Spranger J 2006 Acetylsalicylic acid improves lipidinduced insulin resistance in healthy men. Journal of Clinical Endocrinology and Metabolism 91 964-967. (doi:10.1210/jc.2005-1889)

Myers MG Jr 2006 Role reversal: brain insulin and liver STAT3. Cell Metabolism 3 231-232. (doi:10.1016/j.cmet.2006.03.003)

Newman WP \& Brodows RG 1983 Aspirin causes tissue insensitivity to insulin in normal man. Journal of Clinical Endocrinology and Metabolism 57 1102-1106. (doi:10.1210/jcem-57-6-1102)

Nixon M, Wake DJ, Livingstone DE, Stimson RH, Esteves CL, Seckl JR, Chapman KE, Andrew R \& Walker BR 2012 Salicylate downregulates 11ßHSD1 expression in adipose tissue in obese mice and in humans, mediating insulin sensitization. Diabetes 61 790-796. (doi:10.2337/db11-0931)

Okamoto H, Obici S, Accili D \& Rossetti L 2005 Restoration of liver insulin signaling in Insr knockout mice fails to normalize hepatic insulin action. Journal of Clinical Investigation 115 1314-1322. (doi:10.1172/ JCI23096)

Ouchi N, Kobayashi H, Kihara S, Kumada M, Sato K, Inoue T, Funahashi T \& Walsh K 2004 Adiponectin stimulates angiogenesis by promoting crosstalk between AMP-activated protein kinase and Akt signaling in endothelial cells. Journal of Biological Chemistry 279 1304-1309. (doi:10.1074/jbc.M310389200)

Park E, Oprescu AI, Lam L \& Giacca A 2005 Salicylate does not prevent hepatic insulin resistance caused by prolonged infusion of olive oil. Canadian Journal of Diabetes 29314.

Park E, Wong V, Guan X, Oprescu AI \& Giacca A 2007 Salicylate prevents hepatic insulin resistance caused by short-term elevation of free fatty acids in vivo. Journal of Endocrinology 195 323-331. (doi:10.1677/JOE07-0005)

Posey KA, Clegg DJ, Printz RL, Byun J, Morton GJ, Vivekanandan-Giri A, Pennathur S, Baskin DG, Heinecke JW, Woods SC et al. 2009 Hypothalamic proinflammatory lipid accumulation, inflammation, and insulin resistance in rats fed a high-fat diet. American Journal of Physiology. Endocrinology and Metabolism 296 E1003-E1012. (doi:10.1152/ajpendo.90377.2008)

Samuel VT, Liu ZX, Wang A, Beddow SA, Geisler JG, Kahn M, Zhang XM, Monia BP, Bhanot S \& Shulman GI 2007 Inhibition of protein kinase Cepsilon prevents hepatic insulin resistance in nonalcoholic fatty liver disease. Journal of Clinical Investigation 117 739-745. (doi:10.1172/ JCI30400) 
Schmitz-Peiffer C, Craig DL \& Biden TJ 1999 Ceramide generation is sufficient to account for the inhibition of the insulin-stimulated PKB pathway in C2C12 skeletal muscle cells pretreated with palmitate. Journal of Biological Chemistry 274 24202-24210. (doi:10.1074/jbc.274.34.24202)

Steele R, Wall JS, De Bodo RC \& Altszuler N 1956 Measurement of size and turnover rate of body glucose pool by the isotope dilution method. American Journal of Physiology 187 15-24.

Su YY, Luo B, Wang HT \& Chen L 2009 Differential effects of sodium salicylate on current-evoked firing of pyramidal neurons and fastspiking interneurons in slices of rat auditory cortex. Hearing Research 253 60-66. (doi:10.1016/j.heares.2009.03.007)

Sun SC, Ganchi PA, Ballard DW \& Greene WC 1993 NF-кB controls expression of inhibitor I $\kappa \mathrm{B} \alpha$ : evidence for an inducible autoregulatory pathway. Science 259 1912-1915. (doi:10.1126/science.8096091)

Traenckner EB, Pahl HL, Henkel T, Schmidt KN, Wilk S \& Baeuerle PA 1995 Phosphorylation of human IкB- $\alpha$ on serines 32 and 36 controls IкB- $\alpha$ proteolysis and NF- $\mathrm{\kappa B}$ activation in response to diverse stimuli. EMBO Journal 14 2876-2883.

Xiao C, Giacca A \& Lewis GF 2009 The effect of high-dose sodium salicylate on chronically elevated plasma nonesterified fatty acid-induced insulin resistance and B-cell dysfunction in overweight and obese nondiabetic men. American Journal of Physiology. Endocrinology and Metabolism 297 E1205-E1211. (doi:10.1152/ajpendo.00313.2009)

Yamauchi T, Nio Y, Maki T, Kobayashi M, Takazawa T, Iwabu M, Okada-Iwabu M, Kawamoto S, Kubota N, Kubota T et al. 2007 Targeted disruption of AdipoR1 and AdipoR2 causes abrogation of adiponectin binding and metabolic actions. Nature Medicine 13 332-339. (doi:10.1038/nm1557)

Yin MJ, Yamamoto Y \& Gaynor RB 1998 The anti-inflammatory agents aspirin and salicylate inhibit the activity of IкB kinase- $\beta$. Nature 396 77-80. (doi:10.1038/23948)

Yuan M, Konstantopoulos N, Lee J, Hansen L, Li ZW, Karin M \& Shoelson SE 2001 Reversal of obesity- and diet-induced insulin resistance with salicylates or targeted disruption of Ikk $\beta$. Science 293 1673-1677. (doi:10.1126/science.1061620)

Zandi E, Chen Y \& Karin M 1998 Direct phosphorylation of IкB by IKK $\alpha$ and IKK $\beta$ : discrimination between free and NF-KB-bound substrate. Science 281 1360-1363. (doi:10.1126/science.281. 5381.1360)

Zhang X, Zhang G, Zhang H, Karin M, Bai H \& Cai D 2008 Hypothalamic IKK $\beta / \mathrm{NF}-\mathrm{KB}$ and ER stress link overnutrition to energy imbalance and obesity. Cell 135 61-73. (doi:10.1016/j.cell.2008.07.043)

Received in final form 26 December 2012

Accepted 17 January 2013

Accepted Preprint published online 17 January 2013 